Check for updates

Cite this: RSC Adv., 2019, 9, 17631

\title{
Green synthesis of benzonitrile using ionic liquid with multiple roles as the recycling agent $\uparrow$
}

\author{
Zhihui Li, ${ }^{\text {ab }}$ Tingting Wang, ${ }^{a}$ Xudong Qi, ${ }^{\text {b }}$ Qiusheng Yang, ${ }^{a}$ Liya Gao, ${ }^{a}$ \\ Dongsheng Zhang, ${ }^{* a}$ Xinqiang Zhao a and Yanji Wang (DD *a
}

Preparation of benzonitrile from benzaldehyde and hydroxylamine hydrochloride is one of the most advantageous approaches. Nevertheless, it suffers from various constraints such as longer reaction time, corrosion and recovery of hydrochloric acid, the use of metal salt catalysts and their separation. For these reasons, a novel green benzonitrile synthetic route was proposed with ionic liquid as the recycling agent in this study. The results indicated that hydroxylamine 1-sulfobutyl pyridine hydrosulfate salt $\left(\left(\mathrm{NH}_{2} \mathrm{OH}\right)_{2} \cdot\left[\mathrm{HSO}_{3}-b-\mathrm{Py}\right] \cdot \mathrm{HSO}_{4}\right)$ was an expert alternative to hydroxylamine hydrochloride. Meanwhile, the ionic liquid $\left[\mathrm{HSO}_{3}-b-\mathrm{Py}\right] \cdot \mathrm{HSO}_{4}$ exhibited the multiple roles of co-solvent, catalysis and phase separation, thus the use of metal salt catalyst was eliminated, and no additional catalyst was needed. Hence, the separation process was greatly simplified. When the molar ratio of benzaldehyde to $\left(\mathrm{NH}_{2} \mathrm{OH}\right)_{2} \cdot\left[\mathrm{HSO}_{3}-b-\mathrm{Py}\right] \cdot \mathrm{HSO}_{4}$ was $1: 1.5$, the volume ratio of paraxylene to $\left[\mathrm{HSO}_{3}-b-\mathrm{Py}\right] \cdot \mathrm{HSO}_{4}$ was $2: 1$, the benzaldehyde conversion and benzonitrile yield were both $100 \%$ at $120{ }^{\circ} \mathrm{C}$ in $2 \mathrm{~h}$. Even better, the ionic liquid could be recovered easily by phase separation, and recycled directly after reaction. Additionally, this novel route is applicable to the green synthesis of a variety of aromatic, heteroaromatic and aliphatic nitriles with excellent yields.

Received 26th March 2019

Accepted 18th May 2019

DOI: 10.1039/c9ra02296a

rsc.li/rsc-advances dehydrated to benzonitrile. ${ }^{15,16}$ Both of the two steps can be catalyzed by acid..$^{17,18}$ As for the one-pot route, it includes oximation of benzaldehyde to benzaldoxime, followed by the dehydration of in situ generated benzaldoxime to benzonitrile. ${ }^{19}$ Obviously, the one-pot reaction helps to reduce the energy consumption, solvent waste and reaction time, which in turn, substantially avoids the isolation of benzaldoxime. It is a valuable strategic way in terms of economic and environmental aspects. ${ }^{14}$ Owing to these advantageous features, several studies for the one-pot synthesis of benzonitrile have been conducted in recent years.

Enthaler et al. ${ }^{20}$ presented a direct conversion of benzaldehyde to benzonitrile catalyzed by $\mathrm{Zn}\left(\mathrm{CH}_{3} \mathrm{COO}\right)_{2}(5 \mathrm{~mol} \%)$. When benzaldehyde was $0.72 \mathrm{mmol}, \quad n$ (benzaldehyde) $: n\left(\mathrm{NH}_{2}-\right.$ $\mathrm{OH} \cdot \mathrm{HCl})=1: 1.2$, toluene was $2 \mathrm{~mL}$, reaction temperature was $100{ }^{\circ} \mathrm{C}$, reaction time was $24 \mathrm{~h}$, the benzonitrile yield was $79.0 \%$. Zhuang et al. ${ }^{21}$ studied $\mathrm{SnCl}_{2} \cdot 2 \mathrm{H}_{2} \mathrm{O}(10 \mathrm{~mol} \%)$ catalyzed transformation of benzaldehyde to benzonitrile. When benzaldehyde was $1 \mathrm{mmol}, n$ (benzaldehyde) $: n\left(\mathrm{NH}_{2} \mathrm{OH} \cdot \mathrm{HCl}\right)=1: 1.1$, $\mathrm{CH}_{3} \mathrm{CN}$ was $0.5 \mathrm{~mol}, \mathrm{NaHCO}_{3}$ was $1 \mathrm{mmol}$, the benzonitrile yield was $80.0 \%$ at $80{ }^{\circ} \mathrm{C}$ within $24 \mathrm{~h}$. Leggio et al. ${ }^{22}$ investigated the catalytic properties of $\mathrm{TiCl}_{4}$. When benzaldehyde was $1 \mathrm{mmol}$, $n$ (benzaldehyde) $: n\left(\mathrm{NH}_{2} \mathrm{OH} \cdot \mathrm{HCl}\right)=1: 2$, pyridine was $2 \mathrm{~mL}$, $\mathrm{TiCl}_{4}$ was $2.5 \mathrm{mmol}$, the benzonitrile yield was $85.0 \%$ at $40{ }^{\circ} \mathrm{C}$ in $3 \mathrm{~h}$. Wang et al. ${ }^{19}$ reviewed the synthesis of benzonitrile catalyzed by $\mathrm{NaHSO}_{4} \cdot \mathrm{H}_{2} \mathrm{O}$. Under the optimized conditions of molar ratio of $n($ benzaldehyde $): n\left(\mathrm{NH}_{2} \mathrm{OH} \cdot \mathrm{HCl}\right)=1: 1.4$, and
${ }^{a}$ Hebei Provincial Key Lab of Green Chemical Technology and High Efficient Energy Saving, Hebei University of Technology, Tianjin 300130, China. E-mail: yjwang@ hebut.edu.cn; Tel: +86-22-60200445

${ }^{b}$ School of Energy and Environmental Engineering, Hebei University of Technology, Tianjin 300401, China

$\dagger$ Electronic supplementary information (ESI) available: Experimental and the characterization data. See DOI: 10.1039/c9ra02296a 
reaction at $135{ }^{\circ} \mathrm{C}$ for $4.5 \mathrm{~h}$ in the presence of tetrabutylammonium bromide as phase transfer catalyst and DMF as solvent, benzonitrile was obtained in excellent yield of $92.8 \%$. In addition to homogeneous catalysts, heterogeneous catalysts were also reported. $\mathrm{Fe}_{3} \mathrm{O}_{4}$-CTAB NPs $(1.8 \mathrm{~mol} \%)$ was applied as a competent catalyst for one-pot synthesis of benzonitrile. ${ }^{\mathbf{1 4}}$ The combination of benzaldehyde $(0.5 \mathrm{mmol}), \mathrm{NH}_{2} \mathrm{OH} \cdot \mathrm{HCl}(0.75$ $\mathrm{mmol}), \mathrm{Fe}_{3} \mathrm{O}_{4}$-CTAB NPs $(1.8 \mathrm{~mol} \%)$, and DMF $(5 \mathrm{~mL})$ at $80-$ $90{ }^{\circ} \mathrm{C}$ for $1 \mathrm{~h}$ were found to be the optimized reaction conditions for the desired transformation, with the benzonitrile yield being 97.0\%. A green chitosan supported magnetic ionic liquid (CSMIL) was prepared for direct conversion of benzaldehyde to benzonitrile. ${ }^{23}$ When benzaldehyde was $1 \mathrm{mmol}, \mathrm{NH}_{2} \mathrm{OH} \cdot \mathrm{HCl}$ was $1.2 \mathrm{mmol}$, dry-CSMIL was $15 \mathrm{mg}, \mathrm{MeSO}_{2} \mathrm{Cl}$ was $1.2 \mathrm{mmol}$, the benzonitrile yield was $93.0 \%\left(70{ }^{\circ} \mathrm{C}, 1.5 \mathrm{~h}\right)$. It can be seen that benzonitrile could be efficiently synthesized from benzaldehyde and $\mathrm{NH}_{2} \mathrm{OH} \cdot \mathrm{HCl}$. However, it suffers from various constrains such as longer reaction time, use of metal salt catalysts and inconvenient post treatment. ${ }^{\mathbf{2 4 , 2 5}}$ Furthermore, the using of $\mathrm{NH}_{2} \mathrm{OH} \cdot \mathrm{HCl}$ will inevitably lead to problems of equipment corrosion and environmental pollution because it releases $\mathrm{HCl}$.

Recently, a series of ionic liquids (ILs) were used as alternatives to conventional inorganic acids in hydroxylamine stabilization, leading to the formation of several eco-friendly hydroxylamine ionic liquid salts $\left(\left(\mathrm{NH}_{2} \mathrm{OH}\right)_{2} \cdot \mathrm{ILs}\right)$ that exhibited better reactivity in one-step clean synthesis of caprolactam, phenol and aniline in comparison with $\mathrm{NH}_{2} \mathrm{OH} \cdot \mathrm{HCl}$ and $\left(\mathrm{NH}_{2} \mathrm{OH}\right)_{2} \cdot \mathrm{H}_{2} \mathrm{SO}_{4} \cdot{ }^{26-28}$ In continuation of our work for application of these $\left(\mathrm{NH}_{2} \mathrm{OH}\right)_{2} \cdot \mathrm{ILs}$, a green and high efficient reaction route was developed for direct synthesis of benzonitrile from benzaldehyde and $\left(\mathrm{NH}_{2} \mathrm{OH}\right)_{2} \cdot \mathrm{ILS}$ with ILs as the co-solvent, catalyst, phase separation and recycling agent, as shown in Scheme 1. Compared with the existing method with $\mathrm{NH}_{2} \mathrm{OH} \cdot \mathrm{HCl}$ as raw material, this novel route has the following advantages: (1) it is eco-friendly since no metal salt catalyst was added and no inorganic acid was released. (2) When the reaction was completed, the reaction mass was separated into organic phase and aqueous phase automatically. The organic phase could be analyzed by gas chromatography and the ionic liquid in aqueous phase could be easily recovered. (3) The recovered ionic liquid not only can be recycled as the co-solvent and catalyst, but also as the hydroxylamine stabilizer for preparation of

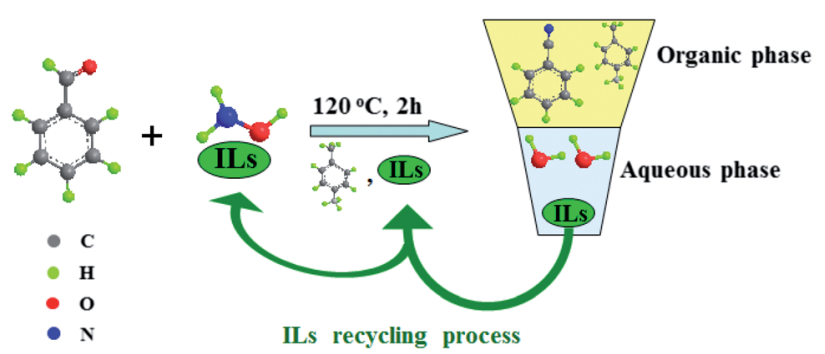

Scheme 1 Green synthesis of benzonitrile using ionic liquid with multiple roles as the recycling agent. The roles of ionic liquid: hydroxylamine stabilizer; co-solvent and catalyst; phase separation; recycled as the co-solvent and catalyst; recycled as the hydroxylamine stabilizer.
$\left(\mathrm{NH}_{2} \mathrm{OH}\right)_{2} \cdot \mathrm{ILs}$. Thus, the recovery of the ionic liquid with multiple roles was fully realized. Moreover, the one-pot clean synthesis of benzonitrile was achieved.

\section{Experimental}

\section{Materials and methods}

All the chemicals (AR grade) were commercially available and used without further purification. FTIR spectra were recorded on a Bruker Vector 22 FTIR spectrometer in the $4000-400 \mathrm{~cm}^{-1}$ range using liquid film or $\mathrm{KBr}$ tablet. The ${ }^{1} \mathrm{H}$ NMR and ${ }^{13} \mathrm{C}$ NMR spectra were recorded on a Bruker AMX FT $400 \mathrm{MHz}$ NMR spectrometer using $\mathrm{D}_{2} \mathrm{O}$ as solvent, and the chemical shifts were expressed in ppm.

\section{Preparation of the $\left(\mathrm{NH}_{2} \mathrm{OH}\right)_{2} \cdot \mathrm{ILS}$}

The $\left(\mathrm{NH}_{2} \mathrm{OH}\right)_{2} \cdot$ ILs were prepared according to the method described in the literature. ${ }^{26,27}$ The synthesis of hydroxylamine 1-sulfobutyl pyridine hydrosulfate salt is given here as an example. 1-Sulfobutyl pyridine hydrosulfate $\left(\left[\mathrm{HSO}_{3}-b\right.\right.$-Py $] \cdot \mathrm{HSO}_{4}$, $32.0 \mathrm{mmol}$ ) was added into a $250 \mathrm{~mL}$ three-necked flask equipped with a dropping funnel and a stirrer. The flask was then placed in a low-temperature reaction bath, and the temperature was continuously kept under $2{ }^{\circ} \mathrm{C}$. The aqueous solution of hydroxylamine $(80.0 \mathrm{mmol})$ was added dropwise to the three-necked flask that contained the $\left[\mathrm{HSO}_{3}-b\right.$-Py $] \mathrm{HSO}_{4}$ while stirring. When the neutralization process was completed, a clear solution was obtained. The solution was then evaporated to dryness under reduced pressure to obtain the white hydroxylamine 1-sulfobutyl pyridine hydrosulfate salt $\left(\left(\mathrm{NH}_{2} \mathrm{OH}\right)_{2}\right.$ $\cdot\left[\mathrm{HSO}_{3}-b\right.$-Py] $\left.\cdot \mathrm{HSO}_{4}\right)$. The preparation method of hydroxylamine $N, N, N$-trimethyl- $N$-sulfobutyl hydrosulfate salt $\left(\left(\mathrm{NH}_{2} \mathrm{OH}\right)_{2}\right.$ $\left.\cdot\left[\mathrm{HSO}_{3}-b-\mathrm{N}\left(\mathrm{CH}_{3}\right)_{3}\right] \cdot \mathrm{HSO}_{4}\right)$ and hydroxylamine 1-sulfobutyl-3methyl imidazole hydrosulfate salt $\left(\left(\mathrm{NH}_{2} \mathrm{OH}\right)_{2} \cdot\left[\mathrm{HSO}_{3}-b-\mathrm{mim}\right]\right.$. $\left.\mathrm{HSO}_{4}\right)$ were similar to that of the $\left(\mathrm{NH}_{2} \mathrm{OH}\right)_{2} \cdot\left[\mathrm{HSO}_{3}-b\right.$-Py $] \cdot \mathrm{HSO}_{4}$, the only difference was to replace the $\left[\mathrm{HSO}_{3}-b\right.$ - $\left.\mathrm{Py}\right] \cdot \mathrm{HSO}_{4}$ with $\left[\mathrm{HSO}_{3}-b-\mathrm{N}\left(\mathrm{CH}_{3}\right)_{3}\right] \cdot \mathrm{HSO}_{4}$ or $\left[\mathrm{HSO}_{3}-b\right.$-mim $] \cdot \mathrm{HSO}_{4} \cdot{ }^{27,28}$

\section{One-pot synthesis of benzonitrile from benzaldehyde and $\left(\mathrm{NH}_{2} \mathrm{OH}\right)_{2} \cdot \mathrm{ILS}$}

The reaction was performed in a $100 \mathrm{~mL}$ three-necked flask equipped with a stirrer and a reflux condenser. Typically, benzaldehyde $(14.4 \mathrm{mmol}),\left(\mathrm{NH}_{2} \mathrm{OH}\right)_{2} \cdot\left[\mathrm{HSO}_{3}-b\right.$-Py] $\cdot \mathrm{HSO}_{4}(21.6$ $\mathrm{mmol}),\left[\mathrm{HSO}_{3}-b-\mathrm{Py}\right] \cdot \mathrm{HSO}_{4}(16 \mathrm{~mL})$ and the organic solvent (32 $\mathrm{mL}$ ) were charged into the flask, and the reaction mixture was heated in an oil bath at $90-120{ }^{\circ} \mathrm{C}$ and kept for $0.5-2 \mathrm{~h}$. Along with the reaction, the organic components $(1 \mathrm{~mL})$ were taken every five minutes and analyzed with an Agilent 7890B gas chromatograph connected with a DB-WAX capillary column and a flame ionisation detector (FID). The analysis conditions were as follows: $\mathrm{N}_{2}$ as carrier, FID temperature $320{ }^{\circ} \mathrm{C}$, the injection port temperature $250{ }^{\circ} \mathrm{C}$, and the program-controlled column temperature as follows: initial temperature of $90{ }^{\circ} \mathrm{C}$ for $1 \mathrm{~min}$, increasing to $225{ }^{\circ} \mathrm{C}$ at a rate of $15{ }^{\circ} \mathrm{C} \min ^{-1}$ and holding for 1 min. The benzaldehyde conversion and benzonitrile yield were determined by the area normalization method. 


\section{Recycling of the ILs}

For recycling of the ILs, the one-step synthesis of benzonitrile from benzaldehyde and $\left(\mathrm{NH}_{2} \mathrm{OH}\right)_{2} \cdot\left[\mathrm{HSO}_{3}-b-\mathrm{Py}\right] \cdot \mathrm{HSO}_{4}$ was carried out under optimal reaction conditions. After the reaction, the resulting mixture was cooled and separated into organic phase and aqueous phase automatically. The organic phase was analyzed by gas chromatography, and the leaving ionic liquid in aqueous phase was easily recovered by distilled with a rotary evaporator under vacuum to remove the water. The recovered ILs could be recycled as the co-solvent and catalyst for one-pot synthesis of benzonitrile. Furthermore, it also could be used again as the hydroxylamine stabilizer to synthesis the $\left(\mathrm{NH}_{2} \mathrm{OH}\right)_{2} \cdot\left[\mathrm{HSO}_{3}-b-\mathrm{Py}\right] \cdot \mathrm{HSO}_{4}$.

\section{Results and discussion}

\section{Co-solvent and catalysis role of the ionic liquid}

The effect of solvent on direct synthesis of benzonitrile was presented in Fig. 1. It could be seen that solvent strongly affected the results. When bromobenzene and ortho-dichlorobenzene were used as solvents, the benzaldehyde conversion and benzonitrile yield were relatively low. While toluene, ethylbenzene and paraxylene were used, the benzaldehyde conversion and benzonitrile yield were very high, especially the latter two solvents. The conversion and yield were both improved to over $96.0 \%$. The solvent effect of aryl halide was inferior to that of aromatic hydrocarbon. The probably reason is that, the present reaction includes oximation of benzaldehyde
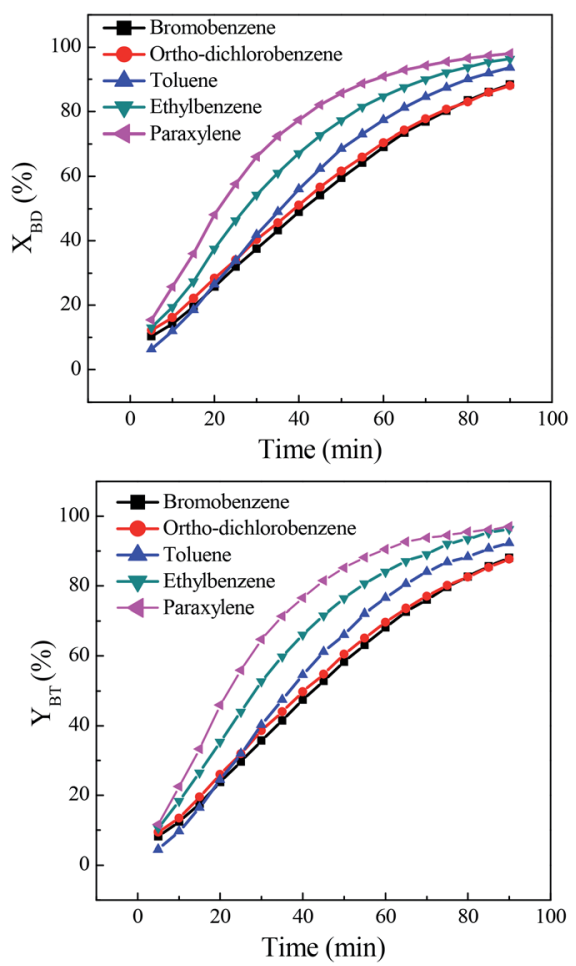

Fig. 1 Effect of solvent on direct synthesis of benzonitrile (BT). Reaction conditions: benzaldehyde (BD) $14.4 \mathrm{mmol}, n(\mathrm{BD}): n\left(\left(\mathrm{NH}_{2}{ }^{-}\right.\right.$ $\left.\mathrm{OH})_{2} \cdot\left[\mathrm{HSO}_{3}-b-\mathrm{Py}\right] \cdot \mathrm{HSO}_{4}\right)=1: 1.5$, solvent $32 \mathrm{~mL},\left[\mathrm{HSO}_{3}-b-\mathrm{Py}\right] \cdot \mathrm{HSO}_{4}$ $16 \mathrm{~mL}$, temperature $100^{\circ} \mathrm{C}$. to benzaldoxime, followed by the dehydration of the in situ generated benzaldoxime to benzonitrile. Being a multistep process, the outcome of the reaction depends on the reactivity of the substrate towards both oximation and dehydration step. As for the first step, it is believed that benzaldoxime is produced through the nucleophilic attack of nitrogen electron pairs in the $\mathrm{NH}_{2} \mathrm{OH}$ to the $\mathrm{C}=\mathrm{O}$ carbon in the benzaldehyde. ${ }^{29,30}$ Free $\mathrm{NH}_{2} \mathrm{OH},{ }^{31}$ resulted from the decomposition of hydroxylamine salt, is the nucleophile necessary for conversion of benzaldehyde to the corresponding benzaldoxime. It was evident that, the aromatic hydrocarbon solvent, such as toluene, ethylbenzene and paraxylene, demonstrated an obvious promotion on the decomposition of hydroxylamine salt to form free $\mathrm{NH}_{2} \mathrm{OH},{ }^{32,33}$ since high benzaldehyde conversions were obtained in these solvents. This solvent promoted decomposition role was probably due to the formation of hydrogen bond between the nitrogen electron pairs in the hydroxylamine salts and hydrogen in the solvent. ${ }^{34}$ Among them, paraxylene was a better choice for direct synthesis of benzonitrile.

Besides paraxylene, a certain amount of $\left[\mathrm{HSO}_{3}-b-\mathrm{Py}\right] \cdot \mathrm{HSO}_{4}$ was also added. To clarify their roles, a comparative study on paraxylene alone, $\left[\mathrm{HSO}_{3}-b\right.$-Py] $\cdot \mathrm{HSO}_{4}$ alone and different ratio of paraxylene to $\left[\mathrm{HSO}_{3}-b-\mathrm{Py}\right] \cdot \mathrm{HSO}_{4}$ was made and the results were listed in Table 1 . When paraxylene was added alone, a large number of white particles, which was the undissolved $\left(\mathrm{NH}_{2}-\right.$ $\mathrm{OH})_{2} \cdot\left[\mathrm{HSO}_{3}-b-\mathrm{Py}\right] \cdot \mathrm{HSO}_{4}$, was dispersed in the reaction mass. It indicated that pure paraxylene could not effectively dissolve the $\left(\mathrm{NH}_{2} \mathrm{OH}\right)_{2} \cdot\left[\mathrm{HSO}_{3}-b\right.$-Py $] \cdot \mathrm{HSO}_{4}$, which then inhibited the reaction between benzaldehyde and hydroxylamine, resulting in a low benzaldehyde conversion of $54.8 \%$. Moreover, most of the product was benzaldoxime, the benzonitrile yield was only $2.12 \%$, indicating that paraxylene only acted as solvent and had no catalytic effect. When $\left[\mathrm{HSO}_{3}-b\right.$-Py] $\cdot \mathrm{HSO}_{4}$ was added, the reaction turned to liquid-liquid two phase. It could be concluded that the addition of $\left[\mathrm{HSO}_{3}-b\right.$-Py $] \cdot \mathrm{HSO}_{4}$ was favorable for the dissolution of $\left(\mathrm{NH}_{2} \mathrm{OH}\right)_{2} \cdot\left[\mathrm{HSO}_{3}-b-\mathrm{Py}\right] \cdot \mathrm{HSO}_{4}$. Moreover, $\left[\mathrm{HSO}_{3}-b\right.$-Py $] \cdot \mathrm{HSO}_{4}$ being a Brønsted acid coordinated with the carbonyl oxygen of benzaldehyde thus increasing its electrophilicity and facilitating its reaction with hydroxylamine. Therefore, the $\left[\mathrm{HSO}_{3}-b\right.$-Py] $\cdot \mathrm{HSO}_{4}$ prompted the benzaldehyde oximation. The benzaldehyde conversion was greatly increased to over $95 \%$. Furthermore, when the $\left[\mathrm{HSO}_{3}-b-\mathrm{Py}\right] \cdot \mathrm{HSO}_{4}$ was

Table 1 The amount of paraxylene and $\left[\mathrm{HSO}_{3}-b-\mathrm{Py}\right] \cdot \mathrm{HSO}_{4}$ on direct synthesis of benzonitrile ${ }^{a}$

\begin{tabular}{lllcc}
\hline No & Paraxylene $(\mathrm{mL})$ & {$\left[\mathrm{HSO}_{3}-b-\mathrm{Py}\right] \cdot \mathrm{HSO}_{4}(\mathrm{~mL})$} & $X_{\mathrm{BD}}(\%)$ & $Y_{\mathrm{BT}}(\%)$ \\
\hline 1 & 12 & 0 & 54.8 & 2.12 \\
2 & 10 & 2 & 95.0 & 92.0 \\
3 & 8 & 4 & 98.0 & 97.0 \\
4 & 6 & 6 & 98.8 & 96.9 \\
5 & 4 & 8 & 100 & 96.7 \\
6 & 0 & 12 & 100 & 96.3 \\
$7^{b}$ & 12 & 0 & 3.71 & 2.43 \\
$8^{c}$ & 12 & 0 & 3.34 & 6.29
\end{tabular}

${ }^{a}$ Reaction conditions: benzaldehyde $3.6 \mathrm{mmol}, n(\mathrm{BD}): n\left(\mathrm{NH}_{2} \mathrm{OH}\right)=$ $1: 3$, temperature $100{ }^{\circ} \mathrm{C}$, time $90 \mathrm{~min} .{ }^{b} \mathrm{NH}_{2} \mathrm{OH} \cdot \mathrm{HCl}$. ${ }^{c}\left(\mathrm{NH}_{2} \mathrm{OH}\right)_{2} \cdot \mathrm{H}_{2} \mathrm{SO}_{4}$. 
added alone, the reaction was homogeneous. The benzaldehyde conversion and benzonitrile yield were 100\% and 96.3\% respectively, which were much higher than those in pure paraxylene. The results demonstrated that $\left[\mathrm{HSO}_{3}-b-\mathrm{Py}\right] \cdot \mathrm{HSO}_{4}$ not only can be used as solvent to promote the benzaldehyde oximation, but also as catalyst to promote the benzaldoxime dehydration..$^{35-37}$

Considering that when the $\left[\mathrm{HSO}_{3}-b-\mathrm{Py}\right] \cdot \mathrm{HSO}_{4}$ alone was applied as both the solvent and catalyst, the reaction liquid was too viscous to separate and recover the ionic liquid. For this reason, a mixture of paraxylene and $\left[\mathrm{HSO}_{3}-b-\mathrm{Py}\right] \cdot \mathrm{HSO}_{4}$ were employed as solvent for the synthesis of benzonitrile. It can be seen that the benzonitrile yield was related to their ratio. With the increase of the amount of $\left[\mathrm{HSO}_{3}-b-\mathrm{Py}\right] \cdot \mathrm{HSO}_{4}$, the benzonitrile yield improved first, then remained almost unchanged. The benzonitrile yield reached a maximum value of $97.0 \%$ when the volume ratio of paraxylene and $\left[\mathrm{HSO}_{3}-b-\mathrm{Py}\right] \cdot \mathrm{HSO}_{4}$ was $2: 1$. With $\mathrm{NH}_{2} \mathrm{OH} \cdot \mathrm{HCl}$ and $\left(\mathrm{NH}_{2} \mathrm{OH}\right)_{2} \cdot \mathrm{H}_{2} \mathrm{SO}_{4}$ as raw materials and paraxylene as a solvent, the benzaldehyde conversion and benzonitrile yield were extremely low, which verified the cosolvent and catalytic role of the $\left[\mathrm{HSO}_{3}-b-\mathrm{Py}\right] \cdot \mathrm{HSO}_{4}$.

\section{Influence of reaction parameters on direct synthesis of benzonitrile}

(1) Temperature. The influence of reaction temperature on direct synthesis of benzonitrile was depicted in Fig. 2. It could be seen that the benzaldehyde conversion and benzonitrile yield were relatively low when the temperature was $90{ }^{\circ} \mathrm{C}$. Meanwhile, the reaction rate was slower since it took longer time to achieve the same conversion and yield. However, the benzaldehyde conversion and benzonitrile yield increased significantly with rising temperature from 90 to $120{ }^{\circ} \mathrm{C}$. The reaction rate also increased rapidly, indicating that higher reaction temperature could enhance the reaction rate, favoring the synthesis of benzonitrile. The highest conversion and yield obtained $\left(120^{\circ} \mathrm{C}\right)$ were $99.9 \%$ and $99.7 \%$ respectively.

(2) Time. The influence of reaction time was also investigated to see whether the benzaldehyde conversion and benzonitrile yield could reach $100 \%$ by prolonging the time. As shown in Fig. 3, the benzaldehyde conversion and benzonitrile yield depended greatly on time at the early stage of reaction. They increased rapidly with the extension of time, and reached a value of $98.6 \%$ and $98.4 \%$ respectively when the time was $1 \mathrm{~h}$. Then the benzaldehyde conversion and benzonitrile yield increased slightly when further prolonging the time. When the reaction time was $2 \mathrm{~h}$, they both reached a value of $100 \%$.

\section{Reactivity comparison of various hydroxylamine salts}

A comparison between the $\left(\mathrm{NH}_{2} \mathrm{OH}\right)_{2} \cdot\left[\mathrm{HSO}_{3}-b\right.$-Py $] \cdot \mathrm{HSO}_{4}$ and other $\left(\mathrm{NH}_{2} \mathrm{OH}\right)_{2} \cdot \mathrm{ILs}$, as well as the traditional hydroxylamine inorganic acid salts was summarized in Table 2. It can be seen that $\left(\mathrm{NH}_{2} \mathrm{OH}\right)_{2} \cdot\left[\mathrm{HSO}_{3}-b-\mathrm{mim}\right] \cdot \mathrm{HSO}_{4}$ and $\left(\mathrm{NH}_{2} \mathrm{OH}\right)_{2} \cdot\left[\mathrm{HSO}_{3}-b\right.$ $\mathrm{Py}] \cdot \mathrm{HSO}_{4}$ demonstrated better reactivity than $\left(\mathrm{NH}_{2} \mathrm{OH}\right)_{2} \cdot\left[\mathrm{HSO}_{3}-\right.$ $\left.b-\mathrm{N}\left(\mathrm{CH}_{3}\right)_{3}\right] \cdot \mathrm{HSO}_{4}$. The benzonitrile yield was around $99.9 \%$ and $100 \%$, respectively. No other by-products were generated.
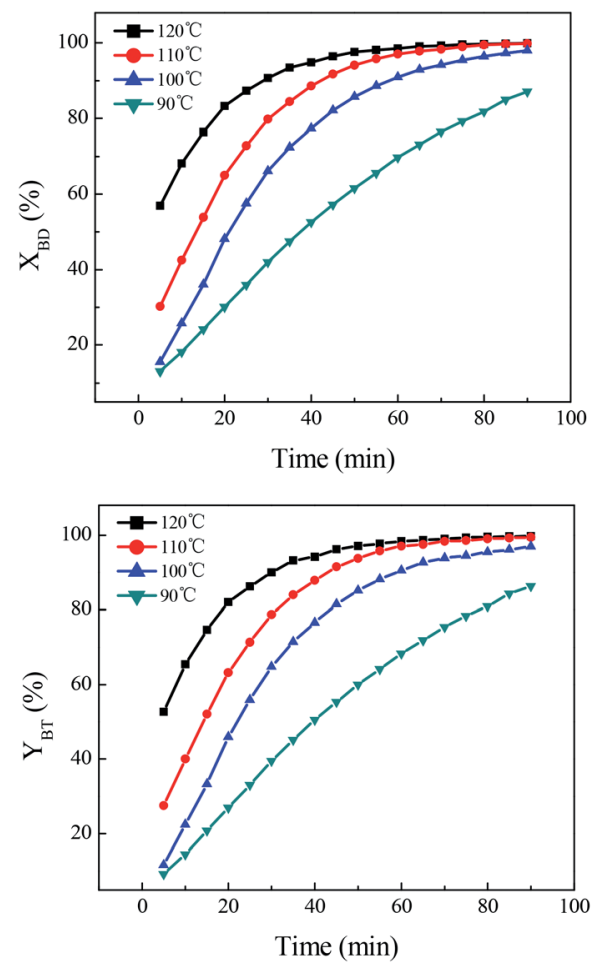

Fig. 2 Effect of temperature on direct synthesis of benzonitrile. Reaction conditions: benzaldehyde $14.4 \mathrm{mmol}, n(\mathrm{BD}): n\left(\left(\mathrm{NH}_{2} \mathrm{OH}\right)_{2}{ }^{-}\right.$ $\left.\cdot\left[\mathrm{HSO}_{3}-b-\mathrm{Py}\right] \cdot \mathrm{HSO}_{4}\right)=1: 1.5$, paraxylene $32 \mathrm{~mL}$, $\left[\mathrm{HSO}_{3}-b-\mathrm{Py}\right] \cdot \mathrm{HSO}_{4}$ $16 \mathrm{~mL}$.

Ionic liquid was reported to be the catalyst for the dehydration of benzaldehyde oxime. ${ }^{35-37}$ The dehydration process could be promoted by the protonation of hydroxyl group in the benzaldehyde oxime through the $\mathrm{H}^{+}$provided by the ionic liquid, converted this moiety to a better leaving group and thus facilitated the formation of benzonitrile. ${ }^{36}$ In order to explore the relationship between the catalytic performance and properties of the ionic liquids, which were combined in the $\mathrm{NH}_{2}-$ $\mathrm{OH})_{2} \cdot \mathrm{ILs}$, their acid strengths were measured according to the method reported previously. ${ }^{38}$ The results were shown in Table 3 and Fig. S1, $\dagger$ from which we can see that the acid strength order is as follows: $\left[\mathrm{HSO}_{3}-b-\mathrm{N}\left(\mathrm{CH}_{3}\right)_{3}\right] \cdot \mathrm{HSO}_{4}<\left[\mathrm{HSO}_{3}-b-\mathrm{mim}\right] \cdot \mathrm{HSO}_{4} \approx$

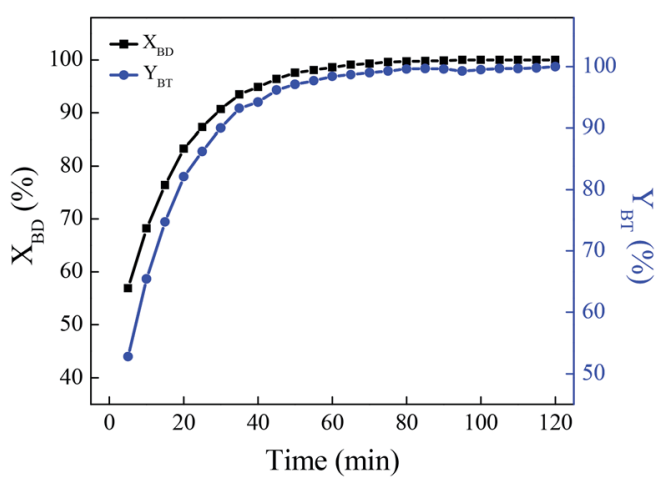

Fig. 3 Effect of time on direct synthesis of benzonitrile. Reaction conditions: benzaldehyde $14.4 \mathrm{mmol}, n(\mathrm{BD}): n\left(\left(\mathrm{NH}_{2} \mathrm{OH}\right)_{2} \cdot\left[\mathrm{HSO}_{3}-b-\right.\right.$ $\left.\mathrm{Py}] \cdot \mathrm{HSO}_{4}\right)=1: 1.5$, paraxylene $32 \mathrm{~mL}$, $\left[\mathrm{HSO}_{3}-b-\mathrm{Py}\right] \cdot \mathrm{HSO}_{4} 16 \mathrm{~mL}$, temperature $120{ }^{\circ} \mathrm{C}$. 
Table 2 Effect of different hydroxylamine salts on direct synthesis of benzonitrile ${ }^{a}$

\begin{tabular}{llcc}
\hline No & Hydroxylamine salt & $X_{\mathrm{BD}}(\%)$ & $Y_{\mathrm{BT}}(\%)$ \\
\hline 1 & $\left(\mathrm{NH}_{2} \mathrm{OH}\right)_{2} \cdot\left[\mathrm{HSO}_{3}-b-\mathrm{N}\left(\mathrm{CH}_{3}\right)_{3}\right] \cdot \mathrm{HSO}_{4}{ }^{b}$ & 84.3 & 84.3 \\
2 & $\left(\mathrm{NH}_{2} \mathrm{OH}\right)_{2}\left[\mathrm{HSO}_{3}-b-\mathrm{mim}\right] \cdot \mathrm{HSO}_{4}{ }^{c}$ & 99.9 & 99.9 \\
3 & $\left(\mathrm{NH}_{2} \mathrm{OH}\right)_{2} \cdot\left[\mathrm{HSO}_{3}-b-\mathrm{Py}\right] \cdot \mathrm{HSO}_{4}{ }^{d}$ & 100 & 100 \\
4 & $\mathrm{NH}_{2} \mathrm{OH} \cdot \mathrm{HCl}^{d}$ & 99.7 & 99.7 \\
5 & $\left(\mathrm{NH}_{2} \mathrm{OH}\right)_{2} \cdot \mathrm{H}_{2} \mathrm{SO}_{4}{ }^{d}$ & 94.3 & 94.3
\end{tabular}

${ }^{a}$ Reaction conditions: benzaldehyde $3.6 \mathrm{mmol}, n(\mathrm{BD}): n\left(\mathrm{NH}_{2} \mathrm{OH}\right)=$ $1: 3$, paraxylene $8 \mathrm{~mL}$, IL $4 \mathrm{~mL}$, temperature $120{ }^{\circ} \mathrm{C}$, time $2 \mathrm{~h} .{ }^{b} \mathrm{IL}$ is $\left[\mathrm{HSO}_{3}-b-\mathrm{N}\left(\mathrm{CH}_{3}\right)_{3}\right] \cdot \mathrm{HSO}_{4} \cdot{ }^{c} \mathrm{IL}$ is $\left[\mathrm{HSO}_{3}-b-\mathrm{mim}\right] \cdot \mathrm{HSO}_{4} \cdot{ }^{d} \mathrm{IL}$ is $\left[\mathrm{HSO}_{3}-b-\right.$ $\mathrm{Py}] \cdot \mathrm{HSO}_{4}$.

$\left[\mathrm{HSO}_{3}-b-\mathrm{Py}\right] \cdot \mathrm{HSO}_{4}$, which was in accordance with their catalytic activity. Thus it could be deduced that the catalytic performance of ionic liquids depended greatly on their acid strength. The ionic liquid with greater acid intensity had the stronger ability to give proton and higher catalytic activity. Moreover, the reactivity of $\left(\mathrm{NH}_{2} \mathrm{OH}\right)_{2} \cdot\left[\mathrm{HSO}_{3}-b\right.$-Py] $\cdot \mathrm{HSO}_{4}$ was better than that of $\left(\mathrm{NH}_{2} \mathrm{OH}\right)_{2} \cdot \mathrm{H}_{2} \mathrm{SO}_{4}$ and $\mathrm{NH}_{2} \mathrm{OH} \cdot \mathrm{HCl}$. Hence, $\left(\mathrm{NH}_{2} \mathrm{OH}\right)_{2} \cdot\left[\mathrm{HSO}_{3}-b-\right.$ $\mathrm{Py}] \cdot \mathrm{HSO}_{4}$ was regarded to be a better alternative to traditional hydroxylamine salts.

\section{Plausible mechanism for the present reaction}

Based on the reported reaction mechanism for aldehyde and hydroxylamine to produce aldehyde oxime, ${ }^{30,31}$ followed by benzaldoxime dehydration to benzonitrile, ${ }^{35,36}$ a plausible

Table 3 Calculation and comparison of $\mathrm{H}_{0}$ values of different ionic liquids $^{a}$

\begin{tabular}{llcccc}
\hline No & IL & $A_{\max }$ & $I(\%)$ & $\mathrm{HI}(\%)$ & $H_{0}$ \\
\hline 1 & Blank & 0.53 & 100 & & \\
2 & {$\left[\mathrm{HSO}_{3}-b-\mathrm{N}\left(\mathrm{CH}_{3}\right)_{3}\right] \cdot \mathrm{HSO}_{4}$} & 0.44 & 83.0 & 17.0 & 1.68 \\
3 & {$\left[\mathrm{HSO}_{3}-b-\mathrm{mim}\right] \cdot \mathrm{HSO}_{4}$} & 0.38 & 71.7 & 28.3 & 1.39 \\
4 & {$\left[\mathrm{HSO}_{3}-b-\mathrm{Py}\right] \cdot \mathrm{HSO}_{4}$} & 0.37 & 69.8 & 30.2 & 1.35
\end{tabular}

${ }^{a}$ Indicator: 4-nitroaniline (5 $\left.\mathrm{mg} \mathrm{L}^{-1}, \mathrm{p} K_{\mathrm{a}}=+0.99\right)$, ILs $\left(5 \mathrm{mmol} \mathrm{L}^{-1}\right)$.

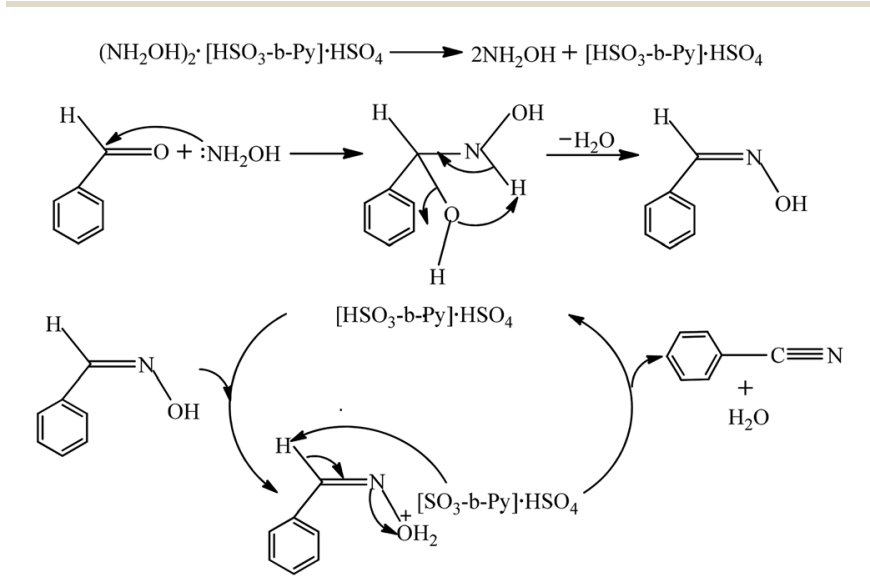

Scheme 2 Plausible mechanism for synthesis of benzonitrile from benzaldehyde and $\left(\mathrm{NH}_{2} \mathrm{OH}\right)_{2} \cdot\left[\mathrm{HSO}_{3}-b-\mathrm{Py}\right] \cdot \mathrm{HSO}_{4}$. mechanism for the present reaction was proposed and depicted in Scheme 2. Firstly, free $\mathrm{NH}_{2} \mathrm{OH}$ and $\left[\mathrm{HSO}_{3}-b-\mathrm{Py}\right] \cdot \mathrm{HSO}_{4}$ were released by the decomposition of $\left(\mathrm{NH}_{2} \mathrm{OH}\right)_{2} \cdot\left[\mathrm{HSO}_{3}-b-\mathrm{Py}\right] \cdot \mathrm{HSO}_{4}$. Then a nucleophilic attack of $\mathrm{NH}_{2} \mathrm{OH}$ to benzaldehyde occurred, followed by a dehydration step to form the benzaldehyde oxime. At last, the hydroxyl group in the benzaldehyde oxime was protonated by the $\mathrm{H}^{+}$offered by the $\left[\mathrm{HSO}_{3}-b-\mathrm{Py}\right]$. $\mathrm{HSO}_{4}$ to form the intermediate, which then converted to benzonitrile through a dehydration step, along with the regeneration of $\left[\mathrm{HSO}_{3}-b\right.$-Py] $\cdot \mathrm{HSO}_{4}$ to complete the catalytic cycle.

Table 4 Recycling of the $\left[\mathrm{HSO}_{3}-b-\mathrm{Py}\right] \cdot \mathrm{HSO}_{4}$ as co-solvent and catalyst $^{a}$

\begin{tabular}{lcc}
\hline Recycle times & $X_{\mathrm{BD}}(\%)$ & $Y_{\mathrm{BT}}(\%)$ \\
\hline 1 & 100 & 100 \\
2 & 100 & 100 \\
3 & 99.5 & 99.5 \\
4 & 98.9 & 98.9 \\
5 & 96.7 & 96.7
\end{tabular}

${ }^{a}$ Reaction conditions: benzaldehyde $3.6 \quad \mathrm{mmol}$, $n(\mathrm{BD}): n\left(\left(\mathrm{NH}_{2} \mathrm{OH}\right)_{2} \cdot\left[\mathrm{HSO}_{3}-b-\mathrm{Py}\right] \cdot \mathrm{HSO}_{4}\right)=1: 1.5$, paraxylene $8 \mathrm{~mL}$, $\left[\mathrm{HSO}_{3}-b-\mathrm{Py}\right] \cdot \mathrm{HSO}_{4} 4 \mathrm{~mL}$, temperature $120{ }^{\circ} \mathrm{C}$, time $2 \mathrm{~h}$.

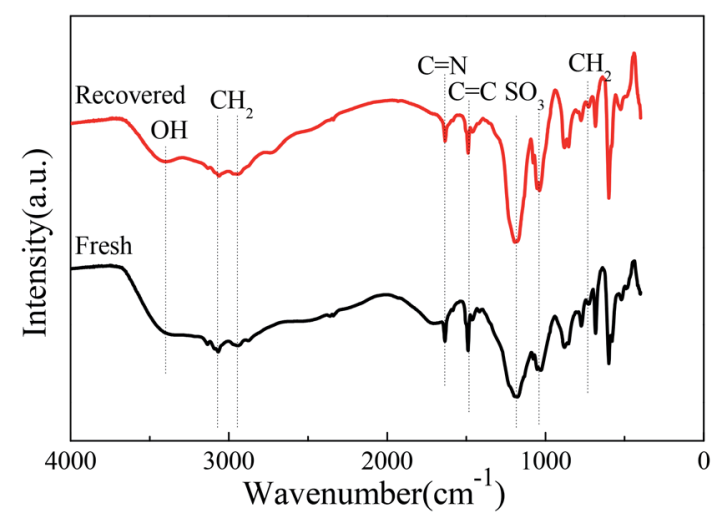

Fig. $4 \mathrm{FTIR}$ spectra of the recovered and fresh $\left[\mathrm{HSO}_{3}-b-\mathrm{Py}\right] \cdot \mathrm{HSO}_{4}$.

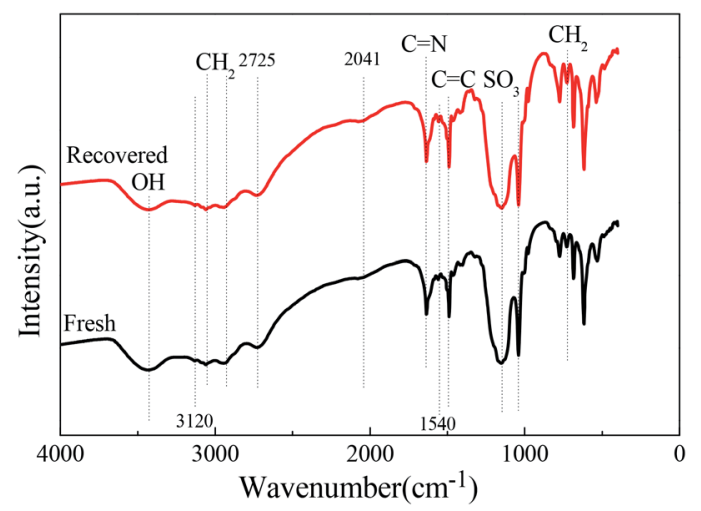

Fig. 5 FTIR spectra of the $\left(\mathrm{NH}_{2} \mathrm{OH}\right)_{2} \cdot\left[\mathrm{HSO}_{3}-b-\mathrm{Py}\right] \cdot \mathrm{HSO}_{4}$ obtained from the recovered and fresh $\left[\mathrm{HSO}_{3}-b-\mathrm{Py}\right] \cdot \mathrm{HSO}_{4}$. 
Table 5 Reactivity of different aldehydes ${ }^{a}$

\begin{tabular}{llll}
\hline No & Aldehyde & Nitrile & $X(\%)$
\end{tabular}

1<smiles>O=Cc1cccc(Br)c1</smiles>

2<smiles>O=Cc1cccc(Cl)c1</smiles>

3<smiles>O=Cc1cccc(F)c1</smiles><smiles>O=Cc1cccc([N+](=O)[O-])c1</smiles>

5

6

7

8

9

10

11

12

13

14

15

16<smiles>O=[N+]([O-])c1ccc(Cl)cc1</smiles><smiles>COc1cccc(C=O)c1</smiles><smiles>COc1ccc(C=O)cc1</smiles><smiles>Cc1ccc(C=O)cc1</smiles>

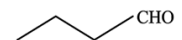<smiles>CCCCC=O</smiles><smiles>CCCCCC=O</smiles><smiles>CCCCCCC=O</smiles><smiles>CCCCCCCC=O</smiles><smiles>O=Cc1ccco1</smiles><smiles>O=Cc1cccs1</smiles><smiles>O=Cc1ccc(C=O)o1</smiles><smiles>N#Cc1cccc(Br)c1</smiles>

80.6

80.6<smiles>N#Cc1cccc(Cl)c1</smiles><smiles>[N]c1cccc(F)c1</smiles><smiles>N#Cc1cccc([N+](=O)[O-])c1</smiles><smiles>N#Cc1ccc([N+](=O)[O-])cc1</smiles><smiles>COc1cccc(C#N)c1</smiles><smiles>COc1ccc(C#N)cc1</smiles><smiles>Cc1ccc(C)cc1</smiles><smiles>CCCC#N</smiles><smiles>CCCCC#N</smiles><smiles>CCCCCC#N</smiles><smiles>CCCCCCC#N</smiles><smiles>CCCCCCCC#N</smiles><smiles>N#Cc1ccco1</smiles><smiles>N#Cc1cccs1</smiles><smiles>N#Cc1ccc(C#N)o1</smiles>

\footnotetext{
${ }^{a}$ Reaction conditions: aldehyde $3.6 \mathrm{mmol}, n($ aldehyde $): n\left(\left(\mathrm{NH}_{2} \mathrm{OH}\right)_{2} \cdot\left[\mathrm{HSO}_{3}-b-\mathrm{Py}\right] \cdot \mathrm{HSO}_{4}\right)=1: 1.5$, paraxylene $8 \mathrm{~mL},\left[\mathrm{HSO}{ }_{3}-b-\mathrm{Py}\right] \cdot \mathrm{HSO}_{4} 4 \mathrm{~mL}$, temperature $120^{\circ} \mathrm{C}$, time $2 \mathrm{~h}$.
}

\section{The recovery and recycling of the ionic liquid}

(1) Recycling of the ionic liquid as co-solvent and catalyst. To investigate the feasibility of the recovery and recycling of the ionic liquid, direct synthesis of benzonitrile from benzaldehyde and $\left(\mathrm{NH}_{2} \mathrm{OH}\right)_{2} \cdot\left[\mathrm{HSO}_{3}-b-\mathrm{Py}\right] \cdot \mathrm{HSO}_{4}$ was carried out under the above mentioned optimal reaction conditions. After completion of the reaction, the resulting mixture was cooled and separated into organic phase and aqueous phase automatically. The organic phase was analyzed by gas chromatography, and the 
leaving ionic liquid in aqueous phase was distilled with a rotary evaporator under vacuum to recover the $\left[\mathrm{HSO}_{3}-b\right.$-Py] $\cdot \mathrm{HSO}_{4}$. The recovered $\left[\mathrm{HSO}_{3}-b\right.$-Py] $\cdot \mathrm{HSO}_{4}$ was further used as co-solvent and catalyst for the next round. It can be seen that the benzaldehyde conversion and benzonitrile yield were still as high as $96.7 \%$ after five times of recycling (Table 4), indicating that $\left[\mathrm{HSO}_{3}-b\right.$ $\mathrm{Py}] \cdot \mathrm{HSO}_{4}$ was stable enough to be recycled.

After the $\left[\mathrm{HSO}_{3}-b\right.$-Py] $\cdot \mathrm{HSO}_{4}$ was recycled for five times, it was recovered, collected and characterized. The FTIR spectra of the recovered and fresh $\left[\mathrm{HSO}_{3}-b\right.$-Py] $\cdot \mathrm{HSO}_{4}$ were similar (Fig. 4). In addition, the ${ }^{1} \mathrm{H}$ NMR and ${ }^{13} \mathrm{C}$ NMR spectra (Fig. S2-S5 $\dagger$ ) of the recovered $\left[\mathrm{HSO}_{3}-b-\mathrm{Py}\right] \cdot \mathrm{HSO}_{4}$ was consistent with that of the fresh $\left[\mathrm{HSO}_{3}-b-\mathrm{Py}\right] \cdot \mathrm{HSO}_{4}$. These results demonstrated that the $\left[\mathrm{HSO}_{3}-b-\mathrm{Py}\right] \cdot \mathrm{HSO}_{4}$ was structurally stable even after recycling five times.

(2) Recycling of the ionic liquid as hydroxylamine stabilizer. $\left[\mathrm{HSO}_{3}-b-\mathrm{Py}\right] \cdot \mathrm{HSO}_{4}$ was recovered when it was recycled for five times, and then reused as the hydroxylamine stabilizer. The $\left(\mathrm{NH}_{2} \mathrm{OH}\right)_{2} \cdot\left[\mathrm{HSO}_{3}-b-\mathrm{Py}\right] \cdot \mathrm{HSO}_{4}$ was prepared again. The FTIR spectra of $\left(\mathrm{NH}_{2} \mathrm{OH}\right)_{2} \cdot\left[\mathrm{HSO}_{3}-b\right.$-Py] $\cdot \mathrm{HSO}_{4}$ obtained from the fresh and recovered $\left[\mathrm{HSO}_{3}-b-\mathrm{Py}\right] \cdot \mathrm{HSO}_{4}$ was presented in Fig. 5 . It can be seen that they were almost identical. The peaks at 3120 and $2725 \mathrm{~cm}^{-1}$ were assigned to the $\mathrm{NH}_{3}{ }^{+}$stretching mode. The peaks at 2041 and $1540 \mathrm{~cm}^{-1}$ were attributed to the characteristic peaks of primary ammonium salt and the $\mathrm{NH}_{3}{ }^{+}$deformation frequencies. ${ }^{26,27}$ Moreover, the ${ }^{1} \mathrm{H}$ NMR and ${ }^{13} \mathrm{C}$ NMR spectra (Fig. S6-S9†) of the $\left(\mathrm{NH}_{2} \mathrm{OH}\right)_{2} \cdot\left[\mathrm{HSO}_{3}-b-\mathrm{Py}\right] \cdot \mathrm{HSO}_{4}$ obtained from the recovered $\left[\mathrm{HSO}_{3}-b\right.$-Py] $\cdot \mathrm{HSO}_{4}$ was consistent with the $\left(\mathrm{NH}_{2} \mathrm{OH}\right)_{2} \cdot\left[\mathrm{HSO}_{3}-b\right.$-Py $] \cdot \mathrm{HSO}_{4}$ obtained from the fresh one, indicating that the recovered $\left[\mathrm{HSO}_{3}-b\right.$-Py] $\cdot \mathrm{HSO}_{4}$ could be used again as the hydroxylamine stabilizer even after it was recycled as co-solvent and catalyst for five times.

$\mathrm{Next}$, the $\left(\mathrm{NH}_{2} \mathrm{OH}\right)_{2} \cdot\left[\mathrm{HSO}_{3}-b-\mathrm{Py}\right] \cdot \mathrm{HSO}_{4}$ obtained from the recovered $\left[\mathrm{HSO}_{3}-b-\mathrm{Py}\right] \cdot \mathrm{HSO}_{4}$ was used in direct synthesis of benzonitrile under the optimal reaction conditions. The benzaldehyde conversion and benzonitrile yield were $100 \%$ and $98.2 \%$, respectively. The results demonstrated that the reactivity of the $\left(\mathrm{NH}_{2} \mathrm{OH}\right)_{2} \cdot\left[\mathrm{HSO}_{3}-b-\mathrm{Py}\right] \cdot \mathrm{HSO}_{4}$ obtained from the recovered and fresh $\left[\mathrm{HSO}_{3}-b\right.$-Py] $\cdot \mathrm{HSO}_{4}$ were much the same.

\section{Reactivity of different aldehydes}

In subsequent efforts, various aldehydes including structurally diverse aryl aldehydes, heterocyclic aldehydes, aliphatic aldehydes, even dialdehyde were chosen as potential substrates to produce their corresponding nitriles (Table 5). For substituted aromatic aldehydes, the substituents and their positions could affect their reactivity. For example, the conversion of the aldehyde with electron withdrawing group was increased along with the enhancement of the electron attract ability (line 1-3, Table 5). Moreover, the results of the para-substituted aldehydes were better than those of the meta-substituted aldehydes (line 4-5, 67, Table 5). For aliphatic aldehydes, the yield of aliphatic nitrile decreased with the increase of the chain length of the aliphatic aldehyde. The conversions of the heterocyclic aldehydes were nearly $100 \%$. As evident from Table 5, stronger electron withdrawing groups (like nitro) have greater influence on the carbonyl group of aromatic aldehydes leading to an increase in its electrophilicity thus increasing the yield of nitrile. This effect is more pronounced for an electron withdrawing substituent in the para position compared to its meta position. Moreover, for aliphatic aldehydes, increasing chain length decreases the electrophilicity of the aldehydic group due to increase in positive inductive effect of the aliphatic chain thus decreasing the overall yield of aliphatic nitriles for higher aliphatic chain aldehydes.

\section{Conclusions}

In summary, a convenient and facile method for direct conversion of aldehydes into nitriles using ionic liquid as the recycling agent has been established. The optimum reaction condition was at $120{ }^{\circ} \mathrm{C}$ for $2 \mathrm{~h}$. The suitable molar ratio of benzaldehyde to $\left(\mathrm{NH}_{2} \mathrm{OH}\right)_{2} \cdot\left[\mathrm{HSO}_{3}-b\right.$-Py] $\cdot \mathrm{HSO}_{4}$ was $1: 1.5$, and the suitable volume ratio of paraxylene to $\left[\mathrm{HSO}_{3}-b-\mathrm{Py}\right] \cdot \mathrm{HSO}_{4}$ was $2: 1$. Under the optimal reaction conditions, the benzaldehyde conversion and benzonitrile yield were both $100 \%$. Ionic liquid exhibited the multiple roles of co-solvent, catalysis and phase separation. It could be recovered easily, and recycled directly after reaction. Additionally, this novel route is applicable to green synthesis of a variety of aromatic, heteroaromatic and aliphatic nitriles with excellent yields.

\section{Conflicts of interest}

The authors declare no competing financial interest.

\section{Acknowledgements}

The authors are grateful for the financial support of the National Natural Science Foundation of China (No. 21236001, 21878069, 21576069 and 201802031), National Natural Science Foundation of Hebei Province (No. B2016202335, B2015202369 and B2017202133).

\section{Notes and references}

1 B. M. Xu, H. Y. Ruan, Y. Zhou, W. Xiong and K. Chen, Chem. World, 2012, 5, 316-320.

2 L. P. OuYang, X. Q. You, Y. Y. Huang, A. Q. Zhang and G. Y. Xie, Appl. Chem. Ind., 2017, 46, 1692-1694.

3 C. H. Yang and J. M. Williams, Org. Lett., 2004, 6, 2837-2840. 4 T. Schareina, A. Zape and M. Beller, Chem. Commun., 2004, 12, 1388-1389.

5 S. Iida, R. Ohmura and H. Togo, Tetrahedron, 2009, 65, 62576262.

6 H. F. Lu, Y. Zhou, H. F. Huang, H. Y. Liu and Y. F. Chen, Chin. J. Catal., 2005, 26, 101-105.

7 E. Rombi, I. Ferino, R. Monaci, C. Picciau, V. Solinas and R. Buzzoni, Appl. Catal., A, 2004, 266, 73-79.

8 K. V. R. Chary, K. R. Reddy, T. Bhaskar and V. S. Guggilla, Green Chem., 2002, 4, 206-209.

9 H. Chen, C. Y. Lu and X. H. Liu, J. Huaihai Inst. Technol., Nat. Sci. Ed., 1997, 6, 51-53. 
10 K. Murugesan, T. Senthamarai, M. Sohail, M. Sharif, N. V. Kalevarua and R. V. Jagadeesh, Green Chem., 2018, 20, 266-273.

11 B. Mitra, G. C. Pariyar, R. Singha and P. Ghosh, Tetrahedron Lett., 2017, 58, 2298-2301.

12 C. J. Fang, M. C. Li, X. Q. Hu, W. M. Mo, B. X. Hu, N. Sun, L. Q. Jin and Z. L. Shen, RSC Adv., 2017, 7, 1484-1489.

13 V. P. Gozum and R. C. Mebane, Green Chem. Lett. Rev., 2013, 6, 149-150.

14 P. Ghosh, B. Saha, G. C. Pariyar, A. Tamang and R. Subba, Tetrahedron Lett., 2016, 57, 3618-3621.

15 S. L. Guan and W. B. Huang, Chem. World, 1993, 9, 418-423. 16 J. M. DeMott Jr and C. J. Kelley, J. Chem. Educ., 2001, 78, 780.

17 S. C. Xu, Organic Chemistry, Higher Education Press, Beijing, 2nd edn, 1993, p.284.

18 S.-I. Fukuzawa, Y. Yamaishi, H. Furuya, K. Terao and F. Iwasaki, Tetrahedron Lett., 1997, 38, 7203-7206.

19 Z. Wang and J. Luo, Fine Chem. Intermed., 2013, 43, 14-18.

20 S. Enthaler, M. Weidauer and F. Schröder, Tetrahedron Lett., 2012, 53, 882-885.

21 Y. J. Zhuang, J. Liu and Y. B. Kang, Tetrahedron Lett., 2016, 57, 5700-5702.

22 A. Leggio, E. L. Belsito, S. Gallo and A. Liguori, Tetrahedron Lett. , 2017, 58, 1512-1514.

23 A. Khalafi-Nezhad and S. Mohammadi, RSC Adv., 2014, 4, 13782-13787.

24 S. H. Khezri, N. Azimi, M. Mohammed-Vali, B. Eftekhari-Sis, M. M. Hashemi, M. H. Baniasadi and F. Teimouri, ARKIVOC, 2007, 15, 162-170.
25 L. V.-B. Hoelz, B. T. Gonçalves, J. C. Barros and J. F. Mendes da Silva, Molecules, 2010, 15, 94-99.

26 Z. H. Li, Q. S. Yang, X. D. Qi, Y. Y. Xu, D. S. Zhang, Y. J. Wang and X. Q. Zhao, Chem. Commun., 2015, 51, 1930-1932.

27 Z. H. Li, Q. S. Yang, L. Y. Gao, Y. Y. Xu, D. S. Zhang, S. F. Wang, X. Q. Zhao and Y. J. Wang, RSC Adv., 2016, 6, 83619-83625.

28 Z. H. Li, X. D. Qi, L. Y. Gao, Y. Y. Xu, D. S. Zhang, S. F. Wang, X. Q. Zhao and Y. J. Wang, Chem. Lett., 2017, 46, 289-292.

29 H. J. Zang, M. L. Wang, B. W. Cheng and J. Song, Ultrason. Sonochem., 2009, 16, 301-303.

30 A. Elmakssoudi, K. Abdelouahdi, M. Zahouily, J. Clark and A. Solhy, Catal. Commun., 2012, 29, 53-57.

31 D. Lorenzo, A. Romero and A. Santos, Ind. Eng. Chem. Res., 2016, 55, 6586-6594.

32 M. Matsumoto, M. Tanimura, T. Akimoto, N. Watanabe and H. K. Ijuin, Tetrahedron Lett., 2008, 49, 4170-4173.

33 O. Phillips, J. M. Schwartz and P. A. Kohl, Polym. Degrad. Stab., 2016, 125, 129-139.

34 J. Wang, X. B. Zhang, F. M. Wang and W. F. Cai, Chem. Ind. Eng. Prog., 2016, 35, 1309-1313.

35 D. Saha, A. Saha and B. C. Ranu, Tetrahedron Lett., 2009, 50, 6088-6091.

36 D. Abolghasem, K. Amir, B. Mehdi and T.-H. Niloofar, Chin. J. Chem., 2011, 29, 978-982.

37 J. L. Zhang, X. R. Chen, Y. P. Yu, K. L. Xu and J. Huang, Chem. Res. Chin. Univ., 2011, 27, 712-714.

38 X. L. Zhang, H. L. An, H. Q. Zhang, X. Q. Zhao and Y. J. Wang, Ind. Eng. Chem. Res., 2014, 53, 16707-16714. 